\title{
Animal deaths turn shuttle into 'necrolab'
}

[WASHINGTON] An unexpectedly high mortality rate among research animals in orbit has complicated a decision by the US space agency on whether to re-fly the Neurolab space shuttle mission this autumn.

Managers at the National Aeronautics and Space Administration (NASA) expect to decide this week if the Neurolab experiments will be repeated to give researchers more data on how the brain and nervous system adapt to spaceflight (see Nature 392, 851; 1998). Before that, however, they would like to understand what caused 57 of 96 newborn rats to die during the two-week flight.

Six of Neurolab's 26 experiments used eight-day-old rats as test subjects to enable researchers to study the effects of weightlessness during the earliest stages of development. But most of the newborn rodents were unable to feed properly from their mothers, became malnourished and died, despite astronauts' attempts to keep them alive.

The high mortality rate disappointed and puzzled mission planners, who thought they had solved a similar problem that occurred on a previous shuttle mission. On that flight, some 60 per cent of five-day-old rats died, but only five per cent of the eight-day-olds were lost.

A NASA Animal Care and Use Committee ruled that only eight-day-olds would be allowed on Neurolab, but now they, too, have suffered high casualties. NASA's chief veterinarian, Joseph Bielitzki, points out that 14day-old and adult rats experienced no such problems on the recent flight. "I wish I could

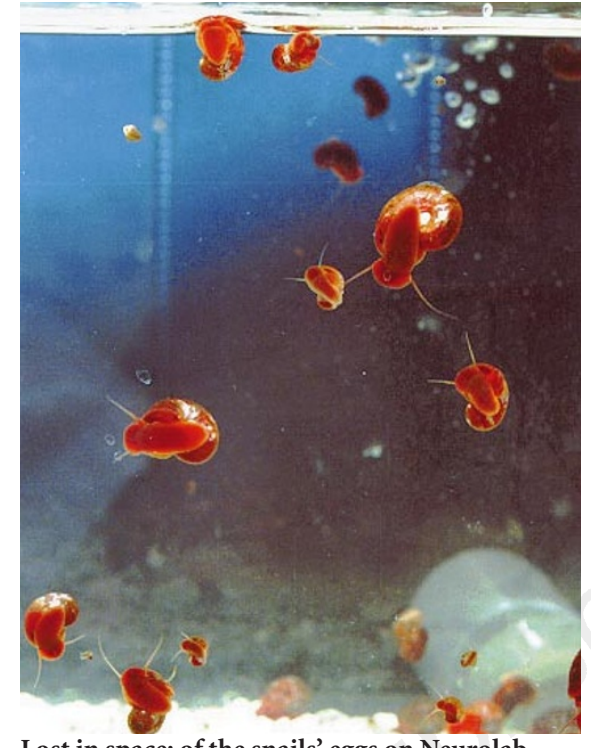

Lost in space: of the snails' eggs on Neurolab, only half the number expected hatched in orbit.

tell you what the big difference was," he says.

Bielitzki says the youngest rats "weren't being confined to the nest adequately" in weightlessness, and had trouble floating back to their mothers inside their Research Animal Holding Facility. A different holding unit, the Animal Enclosure Module, housed eightday-olds on their successful shuttle flight.

Both enclosures are built by NASA's Ames Research Center, and both have about the same volume, but their configurations are different. The enclosure design is one of the areas NASA needs to take a look at, says Bielitzki.
Rats were not the only animals to die unexpectedly on Neurolab. All but 25 of 225 swordtail fish onboard perished when temperatures inside their specialized aquarium become too high. An air-intake line seems to have become clogged, perhaps because the busy astronauts were unable to clean it as often as required.

Less than half the expected number of snail eggs hatched in orbit, and two of four adult oyster toadfish were dead on arrival back on Earth.

Neurolab's research teams were scrambling early this week to make the best of the situation, and most of the scientists say they will be able to meet many of their research goals. But the shortage of test animals has forced teams to share body parts and tissue samples.

In the case of the swordtails, for example, the principal investigator will have just enough samples to meet his own needs. But co-investigators will go wanting.

The experience shows that keeping research animals healthy in space remains an uncertain business. A panel is being formed by NASA and its main partner in the Neurolab project, the National Institutes of Health, to look into why the animals died and "what we need to do to get on with developmental biology in space", says Bielitzki.

Meanwhile, NASA must decide whether to refly Neurolab, with or without the eightday-old rats. The verdict depends in part on US and Russian plans for building the space station, which was to have begun this summer but will now be delayed. Tony Reichhardt

\section{US plan to double spend comes under fire as 'unrealistic exercise'}

[WASHINGTON] An important subcommittee of the US Senate has expressed strong reservations about a plan to double civilian research and development spending over the next ten years, casting yet further doubt on the chances that the ambitious proposal will pass into law.

Senator Bill Frist (Republican, Tennessee), chair of the science, technology and space subcommittee of the Senate Commerce Committee, said after a hearing on the proposed law last week that it was "likely" that his committee would draft an alternative proposal.

The proposed National Research Investment Act, or S1305, is backed by 15 senators, and would set spending limits for all major science agencies that would allow their funding to double over the next ten years. These limits would be reached only if appropriations committees, which exercise the real budgetary power in the Congress, chose to reach them.

Frist says he would prefer a bill that could gather the signatures of 30 or 40 senators and could actually be considered on the Senate floor. "We want to do something that will not be a useless exercise, something that is more than symbolic," he says. Frist adds that the numbers in his bill may be "tied to indices", such as the rate of inflation or growth in national product.

Senator Jay Rockefeller, the senior Democrat on the subcommittee, shares Frist's feelings. "We'll draw up a bill that has a greater chance of passing," he says.

However, observers think there is little chance of either $\mathrm{S} 1305$ or an alternative measure passing the Senate this year.

Senators Phil Gramm (Republican, Texas), Jeff Bingaman (Democrat, New Mexico), Joseph Lieberman (Democrat, Connecticut) and Arlen Specter (Republican, Pennsylvania) all testified before the subcommittee in favour of S1305. Pete Domenici (Republican, New Mexico), chairman of the powerful Budget Committee, who also supports the measure, disappointed his allies by not showing up to testify.

The main point being pushed by the bill's advocates is that it deserves support because its "doubling over ten years" message is, in Lieberman's words, "simple, easily understandable and easy to communicate".

Science lobbyists still hope that Frist and Rockefeller will talk to S1305's supporters and eventually come round to backing a similar measure. In the meantime, they see the proposal as a useful rallying cry for science funding.

But George Brown (Democrat, California), senior Democrat on the House of Representatives Science Committee, made his fiercest attack yet on the measure in addressing a meeting last week of the American Association for the Advancement of Science. "It's a basic scam by a number of senators," he said. "It ain't going to happen, it's impossible; [its supporters] aim to get a lot of good press releases out of it and then forget it after the elections." Colin Macilwain 